\title{
MIRRORS IN JAMES 1:22-25 AND PLATO, ALCIBIADES 132C-133C
}

\section{Nicholas Denyer}

James compares someone who hears the word, but does not do it, to a man who has seen his face in a mirror. There is a stock of putatively parallel passages from biblical, rabbinic and pagan literature, transmitted by one commentator to the next, and recently expanded by L.T. Johnson.' The franker commentators acknowledge however that this stock does little to explain James' comparison. Thus Martin Dibelius says 'the way the metaphor is used in our passage has no points of contact with the known examples [of mirror metaphor in antiquity]', ${ }^{2}$ and Peter H. Davids says 'these uses [of the mirror metaphor] have no relationship to James'. 3

A more promising parallel to James' comparison occurs in Plato's so-called Greater Alcibiades, or Alcibiades I-the longer of the two Alcibiades dialogues ascribed to him. Here Socrates attempts to expound the old maxim 'Know thyself.' He argues that Alcibiades will not be able to take care of himself if he does not know what he himself is (128a-129b). He should therefore appreciate that he, indeed that any human being, is a soul, not a body, nor even a body-plussoul; for example, when Socrates speaks to Alcibiades, he addresses his remarks, not to Alcibiades' face, but to his soul (129b-130e). The old maxim therefore advises a soul to know itself (130e). This intellectual task for the soul can best be understood by comparison with a perceptual task for the body. An eye can see itself by seeing how it is reflected in the pupil of another eye; that is, by seeing how another sees it. Likewise, a soul can know itself by knowing how it is recorded in the intellect of another soul; that is, by knowing how another knows it. The eye will however see itself more clearly if it looks, not into another eye, but into the bigger and brighter reflecting

1 Johnson, L.T., 'The Mirror of Remembrance (James 1:22-25)' Catholic Biblical Quarterly 50 (1988), 632-45.

2 Dibelius, M., James: A Commentary on the Epistle of James, rev. Heinrich Greeven, trans. Michael A. Williams (Philadelphia: Fortress Press, 1976), 115.

3 Davids, P.H., New International Biblical Commentary: James. (Peabody, Mass.: Hendrickson, 1989) 54. 
surface of a mirror. Likewise, a human soul will know itself more clearly if it knows, not how it is known by the intellect of another human soul, but how it is known by God (132c-133c). Moreover, once a soul knows itself, and not before, it will have a proper appreciation of its place in the scheme of things, and act accordingly; and this, and only this, will make it happy (133c-135c).

The key passage is at $132 \mathrm{~d}-133 \mathrm{c}$. It is worth translating in full, with some brief commentary in square brackets. ' $\mathrm{SO}$ ' and ' $\mathrm{AL}$ ' are Socrates and Alcibiades.

SO: If the maxim were giving counsel to our visual apparatus as though to a human being, and said 'See thyself', how would we interpret its advice? Wouldn't it be to look at that, by looking at which the eye was going to see itself?

AL: Clearly it would.

SO: Now do we realise what we have to look at in order to see both it and ourselves simultaneously?

AL: Clearly, Socrates, we have to look at mirrors and things of that sort.

SO: Correct. Now doesn't the eye with which we see contain something of the sort?

AL: Certainly.

SO: You've realised then that when someone looks into an eye, his face appears in the pupil of the person opposite, as though in a mirror? It's what we call a kore [the Greek term for a doll, for an image in the pupil, and indeed for the pupil itself], since it is a little image of the person looking in.

AL: That's true.

SO: So an eye would see itself by gazing on an eye, and by looking into the best part of it, that with which it sees. [Socrates here presupposes the then current theory, which made vision consist in the formation of reflections in the pupil.]

AL: So it seems.

SO: But if it looks at any other part of the person, or anything else at all, with the exception of something that happens to resemble the pupil, then the eye will not see itself.

AL: That's true.

SO: So if an eye is going to see itself, mustn't it look into an eye, and in particular into that region of the visual apparatus which happens to contain the virtue of an eye, namely, sight?

AL: Quite so.

SO: Thus, my dear Alcibiades, if a soul too is going to know itself, then mustn't it look into a soul, and above all into that region of it which contains the virtue of a soul, wisdom, and into something else which this happens to resemble?

AL: I think so, Socrates.

SO: Now could we say that there is any part of the soul more divine than that with which knowledge and understanding are connected?

AL: We could not.

4 I here translate the text given. in John Burnet, Platonis Opera vol. II (Oxford: Clarendon, 1901). 
SO: God therefore is what this part of the soul resembles; and if someone has looked at this and has come to have knowledge of all that is divine, both God and understanding, then this will give him the best knowledge of himself too.

AL: So it seems.

At the heart of the Alcibiades passage is, of course, the standard Platonic distinction between, on the one hand, the fickle, visible and

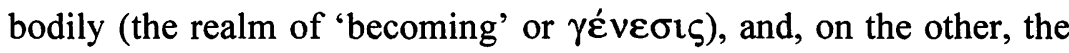
perfect and intelligible realm to which the soul by rights belongs (the realm of 'being' or ov $\sigma i \alpha$ ). Here, as in the analogy of the Line (Republic 509d-511e), both vision (with its contrast between reflections in pupils and clearer reflections in mirrors), and the intellect (with its contrast between human wisdom and the clearer wisdom of God), provide analogies for the way that the realm of vision as a whole is like, but inferior to, the realm of intellect.

Let us now consider James 1:25 in the light of the Alcibiades. The man who looks to the perfect law is like the self-knower in Plato who 'has come to have knowledge of all that is divine, both God and understanding' (133c5), who is 'looking at what is divine and bright' (134d5). The man in James looks to a 'law of freedom'; the virtuous condition of the self-knower in Plato 'befits the free' $(135 \mathrm{c} 6)$. The man in James not only hears but also does the word; Plato's selfknowers 'act correctly and well' (134d10). The man in James is 'blessed in his deed'; the actions of Plato's self-knowers will make them happy (134e1-2).

These similarities suggest reading James 1:23-24 also in the light of the Alcibiades. A man who sees himself in the mirror, if we think of him in Platonic terms, has thereby only an inferior simulacrum of genuine self-knowledge. Like the face he sees, his simulacrum of selfknowledge is confined to the realm of becoming. Of course, as simulacra go, it is not a bad simulacrum. He is, after all, using a reflection in a mirror, not a reflection in a pupil; and he is giving this reflection some scrutiny (in spite of the New English Bible,

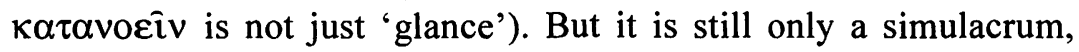
without the stability of the genuine self-knowledge that it simulates. The point is not that he is a particularly stupid man, one who would not recognise his face if he looked in the mirror again, or who cannot remember whether he has a moustache. The point is rather that, however clear his view of himself, it perishes the moment that he leaves the mirror. If the Alcibiades is at all an apposite parallel, then it is this vivid but evanescent awareness that James compares to hearing the word without doing it. 
The Alcibiades was widely read in antiquity as the very best introduction to Plato's thought. ${ }^{5}$ In the nineteenth century, however, the Alcibiades was condemned by Friedrich Schleiermacher as bogus. As a result, it is little read these days, even by classicists; indeed, the first modern commentary on the dialogue still awaits publication. So we need not be surprised, either that the Alcibiades should provide a parallel for James, or that the parallel should be overlooked by New Testament scholarship.

5 Its ancient reputation is documented by Antonio Carlini, ed., Platone: Alcibiade, Alcibiade Secondo, Ipparco, Rivali (Turin: Boringhieri, 1964), 401-403 and A.Ph. Segonds, ed., Proclus: sur le premier Alcibiade de Platon (Paris: Budé, 1985), vol. I, X-xxi. 